\title{
OTONOMI DAERAH DALAM PELAKSANAAN PEMBANGUNAN INFRASTRUKTUR DIKOTA SUNGAI PENUH TAHUN 2019
}

\author{
HERLINDA
}

\author{
STIA Nusantara Sakti Sungai Penuh \\ Email : \\ Herlinda@gmail.com
}

\begin{abstract}
This research took place at the office of the River City Regional Development Planning Agency (BAPPEDA). The purpose of this research is to find out how regional autonomy is in implementing infrastructure development in Sungai Penuh City. The approach taken in this research is qualitative. The number of informants was 7 people. Techniques and data collection tools in this study were interviews, observation, and documentation study. The unit of analysis is the Institute. The institution in this research is the regional development planning agency for Sungai Penuh City. The results show that the infrastructure development in Sungai Penuh City has been carried out by the regional government, however, the local government of Sungai Penuh City is not efficient enough in carrying out infrastructure development in the Sungai Penuh city. Because there are several roads in the Sungai Penuh city area that are still damaged. The weak planning factor in Sungai Penuh city is the natural resource factor, the funding factor, because the land availability in the Sungai Penuh city area is not sufficient, which is. The local government of Sungai Penuh City must be able to control the results of natural wealth so that regional revenue or revenue increases.
\end{abstract}

Keywords : Regional autonomy, Implementation of Infrastructure Development

\begin{abstract}
ABSTRAK
Penelitian ini mengambil lokasi di kantor Badan Perencanaan Pembangunan Daerah (BAPPEDA) Kota Sungai Penuh. Tujuan penelitian ini untuk mengetahui bagaimana otonomi daerah dalam pelaksanaan pembangunan infrastruktur di Kota Sungai Penuh. Pendekatan yang dilakukan dalam penelitian ini adalah kualitatif. Adapun jumlah informan berjumlah 7 orang. Teknik dan alat pungumpulan data dalam penelitian ini adalah wawancara, observasi, dan studi dokumentasi. Unit analisis adalah Lembaga, Lembaga dalam penelitian ini yaitu Badan Perencanaan Pembangunan Daerah Kota Sungai Penuh. Hasil penelitian menunjukkan Pembangunan Infrastruktur di Kota Sungai Penuh sudah terlaksanakan oleh pemerintahan daerah namun, pemerintahan daerah Kota Sungai Penuh belum cukup efisien dalam menjalankan Pembangunan Infrastruktur di Kota Sungai Penuh, Karna ada di beberapa jalan di daerah kota Sungai Penuh masih ada yang rusak. Faktor lemah nya perencanaan di kota
\end{abstract}


Sungai Penuh yaitu factor sumber daya alam dan factor pendanaan, karna ketersediaan lahan di daerah Kota Sungai Penuh belum cukup memadai. Pemerintahan daerah Kota Sungai Penuh harus bias mengendalikan hasil kekayaan alam agar penerimaan atau pemasukan daerah lebih meningkat.

Kata kunci : Otonomi daerah, Pelaksanaan Pembangunan Infrastruktur

\section{PENDAHULUAN}

Dalam perkembangan sistem kekuasaan di Indonesia antara pemerintah pusat dengan pemerintah daerah yang sekarang telah berkembang bahwa adanya otonomi daerah. Pelaksanaan otonomi daerah ini memang tidak semua urusan juga diserahkan kepada pemerintah daerah tetapi adanya pembagian kewenangan yang menuntut pemerintah daerah untuk mempunyai inisiatif dalam merumuskan kebijakan daerah yang sesuai dengan aspirasi, potensi dan sosio-kultural masyarakat daerahnya masing-masing. Pemberian kewenangan dari pusat ke daerah memang dapat menimbulkan dampak positif dan negative bagi pemerintah maupun masyarakat. Untuk itu perlu dipahami terkait kebijakan otonomi daerah di Indonesia yang ditinjau dari prespektif demokrasi.Dalam hal ini diketahui bahwa demokrasi memang mempunyai posisi yang vital dalam kaitannya dengan pembagian kekuasaan dalam suatu Negara. Kekuasaan Negara diperoleh dari rakyat harus digunakan untuk kesejahteraan dan kemakmuran rakyat. Selain itu memang harus dipahami juga terkait kebijakan otonomi daerah di Indonesia yang ditinjau dari prespektif Hak Asasi Manusia. Untuk itu dalam menjalankan otonomi daerah juga harus memperhatikan aspek pemenuhan hak-hak dasar dalam HAM yaitu Hak Sipil dan politik, serta hak ekonomi, social, dan budaya. Diharapkan dengan prespektif kedua hal tersebut pelaksanaan otonomi daerah mampu digunakan untuk meningkatkan kesejahteraan daerah sesuai dengan aspirasi, potensi, dan sosio-kultual setiap daerah.

Adapun pemerintah daerah kabupaten/kota terdiri atas pemerintah daerah kabupaten/kota dan DPRD kabupaten/kota.

UU no 9 tahun 2015 Pemerintah daerah adalah hak,wewenang,dan kewajiban daerah otonom untuk mengatur dan mengurus sendiri urusan pemerintahan dan kepentingan setempat sesuai dengan peraturan perundang undangan.

UU No 33 Tahun 2004 tentang perimbangan keuangan antara pemerintah pusat dengan pemerintah daerah. Dengan otonomi daerah, pemerintah daerah diharapkan semakin mandiri, mengurangi ketergantungan terhadap pemerintah pusat, baik dalam hal pembiayaan pembangunan maupun dalam hal pengelolaan keuangan daerah.

Dana Perimbangan merupakan pendanaan Daerah yang bersumber dari APBN yang terdiri atas Dana Bagi Hasil (DBH), Dana Alokasi Umum (DAU), dan Dana Alokasi Khusus (DAK). Dana Perimbangan selain dimaksudkan untuk membantu Daerah dalam mendanai kewenangannya, juga bertujuan untuk mengurangi ketimpangan sumber pendanaan pemerintahan antara Pusat dan Daerah serta untuk mengurangi kesenjangan pendanaan 
pemerintahan antar-Daerah. Ketiga komponen Dana Perimbangan ini merupakan sistem transfer dana dari Pemerintah serta merupakan satu kesatuan yang utuh.

DBH adalah dana yang bersumber dari pendapatan APBN yang dibagihasilkan kepada Daerah berdasarkan angka persentase tertentu. Pengaturan DBH dalam Undang-Undang ini merupakan penyelarasan dengan Undang-Undang Nomor 7 Tahun 1983 tentang Pajak Penghasilan sebagaimana telah beberapa kali diubah, terakhir dengan Undang-Undang Nomor 17 Tahun 2000. Dalam Undang-Undang ini dimuat pengaturan mengenai Bagi Hasil penerimaan Pajak Penghasilan (PPh) Pasal 25/29 Wajib Pajak Orang Pribadi Dalam Negeri dan PPh Pasal 21 serta sektor pertambangan panas bumi sebagaimana dimaksud dalam Undang-Undang Nomor 27 Tahun 2003 tentang Panas Bumi. Selain itu, dana reboisasi yang semula termasuk bagian dari DAK, dialihkan menjadi DBH.

DAU bertujuan untuk pemerataan kemampuan keuangan antar-Daerah yang dimaksudkan untuk mengurangi ketimpangan kemampuan keuangan antar-Daerah melalui penerapan formula yang mempertimbangkan kebutuhan dan potensi Daerah. DAU suatu Daerah ditentukan atas besar kecilnya celah fiskal (fiscal gap) suatu Daerah, yang merupakan selisih antara kebutuhan Daerah (fiscal need) dan potensi Daerah (fiscal capacity). Dalam Undang-Undang ini ditegaskan kembali mengenai formula celah fiskal dan penambahan variabel DAU. Alokasi DAU bagi Daerah yang potensi fiskalnya besar tetapi kebutuhan fiskal kecil akan memperoleh alokasi DAU relatif kecil. Sebaliknya, Daerah yang potensi fiskalnya kecil, namun kebutuhan fiskal besar akan memperoleh alokasi DAU relatif besar. Secara implisit, prinsip tersebut menegaskan fungsi DAU sebagai faktor pemerataan kapasitas fiskal.

DAK dimaksudkan untuk membantu membiayai kegiatan-kegiatan khusus di Daerah tertentu yang merupakan urusan Daerah dan sesuai dengan prioritas nasional, khususnya untuk membiayai kebutuhan sarana dan prasarana pelayanan dasar masyarakat yang belum mencapai standar tertentu atau untuk mendorong percepatan pembangunan Daerah.

Kesenjangan atau ketimpangan antar daerah menimbulkan dampak negatif dalam aspek ekonomi, dan aspek sosial. Dalam aspek ekonomi, yaitu terjadi perbedaan dalam tingkat pertumbuhan ekonomi dan kesejahteraan masyarakat. Dalam aspek sosial, yaitu terdapatnya pembangunan yang tidak merata yang menimbulkan rasa ketidak adilan dalam masyarakat. Kesenjangan dan ketimpangan antar daerah harus diupayakan dikurangi menjadi sekecil mungkin (seminimal mungkin) dengan melaksanakan berbagai strategi, kebijakan dan program pembangunan yang terintegrasi, terkoordinir, tersinkronisasi, berkelanjutan dan harmonis (Adisasmita, 2015:2). Infrastruktur juga dapat dijadikan mobil penggerak pembangunan nasional dan menjadi konektivitas antar wilayah yang ada di Indonesia. Perbaikan pada sektor infrastruktur tentunya dapat mendorong minat investasi asing dan domestik. Peningkatan pertumbuhan ekonomi Indonesia beberapa tahun terakhir salah satunya ditenggarai karena meningkatnya perhatian pemerintah terhadap investasi infrastruktur. Keberadaan Infrastruktur yang memadai seharunya akan berkontribusi kepada kelancaran produksi maupun distribusi barang dan jasa antar wilayah yang pada akhirnya dapat meningkatkan pertumbuhan ekonomi. Pertumbuhan dan pemerataan ekonomi menjadi indikator untuk melihat hasil dari pembangunan yang telah dilakukan dan dapat menentukan arah pembangunan di masa yang akan datang. 
Pembentukan Kota Sungai Penuh menurut Undang-Undang nomor 25 Tahun 2008 tentang pembentukan Kota Sungai Penuh. Kota Sungai Penuh merupakan pemekaran dari kabupaten Kerinci, terdiri atas delapan (8) kecamatan. Mengungkapkan perkembang Kota Sungai Penuh pada masa Otonomi Daerah tahun 2008 hingga 2019. Di Kota Sungai Penuh yang masih membutuhkanbanyak pembenahan, baik dari segi fisik, prasarana, infrastruktur pembangunan dan otonomi daerah. Dan yang paling utama otonomi daerah di bagian infrastruktur pembangunan di Kota Sungai Penuh.

Yang menjadi fenomena dalam penelitian ini adalah :

1. Bangunan di Kota Sungai Penuh belum merata dan ada jalan di beberapa daerah di Kota Sungai Penuh masih banyak yang berlubang, karna belum efisiennya pelaksana pembangunandi kota sungai penuh .

2. semenjak pemekaran dari tahun 2008 hingga 2019 pembangunan infrasturktur di kota sungai penuh belum jelas terlihat. Karna lemahnya Lembaga perencanaan di kota Sungai Penuh.

3. Berdasarkan data ringkasan APBD Tahun 2019 Kota Sungai Penuh mengalami defisit anggaran sebanyak 36.026.577.052,88 $\mathrm{M}$ hal ini yang menjadi kendala pemerintah Kota Sungai Penuh dalam mengoptimalkan pembangunan infrastruktur di Kota Sungai Penuh.

Semenjak pemekaran Kota Sungai Penuh tidak terlihat adanya perubahan signifikan terhadap pembangunan infrastruktur yang ada di Kota Sungai Penuh. Berdasarkan hal ini, maka peneliti tertarik untuk meneliti bagaimana Otonomi Daerah Dalam Pelaksanaan Pembangunan Infrastruktur di Kota Sungai Penuh.

\section{METODE PENELITIAN}

\section{Pendekatan penelitian yang di gunakan}

Penelitian ini merupakan penelitian kualitatif. Melalui pendekatan ini akan terungkap gambaran mengenai aktualisasi, realisasi social dan persepsi sasaran penelitian. Peneliti dalam hal ini berusaha memahami dan menggambarkan apa yang dipahami dan di gambarkan sejak penelitian. Penelitian kualitatif harus mempertimbangkan metodologi kualitatif itu sendiri.

\section{Informan Penelitin}

Dalam penelitian ini peneliti menggunakan metode purposive sampling, dengan menyertakan informan kunci ( Key Informan ). Informan Kunci adalah informan yang mengetahui secara mendalam permasalahan yang sedang diteliti. Tujuan digunakan teknik purposive sampling yaitu teknik pemilihan informan untuk mendapatkan sumber data dengan pertimbangan tertentu. Pertimbangan ini seperti, orang yang dianggap paling tahu tentang apa yang diharapkan peneliti. Selain itu, pada penelitian ini juga didukung dengan menggunakan teknik snowball sampling, yaitu teknik pengambilan sampel sumber data, yang pada awalnya jumlahnya sedikit, makin lama makin besar, hal ini dilakukan karena dari jumlah sumber data sedikit di perkirakan belum mampu memberikan data yang lengkap. Yang menjadi Informan dalam penelitian ini adalah Kepala bappeda sebagai informan umum, sekretaris bappeda sebagai informan umum, Kabid Perencanaan Pengendalian dan Evaluasi sebagai informan 
umum, Kabid Perekonomian, SDA, Infrastruktur dan Kewilayahan sebagai informan kunci (key informan), Kasubbid Infrastruktur dan SDA sebagai informan umum, Kasubbid Perencanaan sebagai informan umum, Kasubagg program dan keuangan sebagai informan umum.

\section{Data yang akan diambil}

1. Data primer

Data primer yaitu data yang diperoleh langsung dari objek atau subjek yang di teliti. Dalam penelitian ini data primer di dapatkan secara langsung oleh peneliti berdasarkan hasil wawancara yaitu infomasi yang dilontarkan oleh para informan.

2. Data sekunder

Data sekunder adalah data yang berasal dari kantor Badan Perencanaan Pembangunan Daerah (Bappeda) berupa keterangan-keterangan serta laporan-laporan atau dokumentasi .

\section{Teknik dan alat pengumpulan data}

\section{Teknik pengumpulan data}

Wawancara (interview)

Merupakan teknik pengumpulan data dengan berkomunikasi secara langsung dalam bentuk pertanyaan kepada informan untuk mendapatkan informasi atau jawaban mengenai persoalan.

Pengamatan (observastion)

Teknik pengumpulan data melalui pengamatan langsung ke lapangan yang dilakukan dengan melihat aktivitas dari masing-masing objek yang diteliti. Pengamatan dalam penelitian ini dilakukan di Kantor Badan Perencanaan Pembangunan Daerah (Bappeda).

Studi dokumentasi

Teknik pengumpulan data dengan melakukan penelaahaan buku-buku,arsip, kumpulan peraturan perundang-undangan, makalah-makalah,hasil penelitian ilmiah yang berhubungan dengan penelitian ini.

\section{Alat pengumpulan data}

Alat yang digunakan yaitu:

1. Pensil/peta

2. Laptop/notebook

3. Hp (Handphone)

\section{Unit Analisis}

Unit analisis adalah satuan yang menunjuk pada subjek penelitian.adapun unit dalam penilitian ini adalah Lembaga. Lembaga dalam penelitian ini yaitu Badan Perencanaan Pembangunan Daerah (Bappeda).

\section{Analisis data}

Hasil ini uraikan dalam bentuk kalimat bukan angka-angka atau data stastistik. Adapun tahap-tahap analisis data sebagai berikut:

1. Reduksi data

Merupakan kegiatan merangkum, memilih hal-hal pokok, memfokuskan pada hal-hal yang penting dan mencari tema dan polanya. Data yang telah direduksi akan 
memberikan gambaran lebih jelas dan memudahkan untuk melakukan pengumpulan data (sugiyono 2007:92 dalam imam gunawan 2016).

2. Penyajian data

Merupakan sekumpulan informasi tersusun yang memberi kemungkinan adanya penarikan kesimpulan dan pengambilan tindakan dengan melihat penyajian data, peneliti dapat memahami apa yang sedang terjadi apa yang harus dilakukan berdasarkan pemahaman yang di dapatkan peneliti dari penyajian tersebut (M. Djunaidy Ghony 2014:30).

3. Penarikan kesimpulan

Merupakan hasil penelitian yang menjawab fokus penelitian berdasarkan hasil Analisa data (imam gunawan 2016). Untuk menjaga validitas data maka dilakukan triangulasi terhadap data.

Triangulasi data dilakukan dengan cara :

Meminta umpan balik dari informan, umpan balik tersebut berguna untuk memperbaiki kualitas data dan kesimpulan yang ditarik dari data tersebut.

\section{HASIL DAN PEMBAHASAN}

\section{Otonomi Daerah}

Otonomi daerah adalah hak, kewenangan dan kewajiban daerah otonom untuk mengatur dan mengurus sendiri urusan pemerintah dan kepentingan masyarakat setempat sesuai dengan peraturan perundang-undang. Hakikat otomi daerah adalah upaya memperdaya daerah dalam pengambilan keputusan daerah secara lebih leluasa dan bertanggung jawab untuk mengelola sumber daya yang dimiliki sesuai dengan kepentingan, prioritas dan potensi daerah sendiri (simanjuntak, 2013:70).(menurut Suparmoko, 2002:61) mengartikan otonomi daerah adalah kewenangan daerah otonomi untuk mengatur dan mengurus kepentingan masyarakat setempat. Menurut prakarsa sendiri berdasarkan aspirasi masyarakat.

(Abdul Aziz Hakim, 2006: 64-65) berpendapat bahwa dalam hal kekuasaan negara itu dibagi-bagikan, terdapat dua macam pembagian kekuasaan yaitu pembagaian kekuasaan secara vertikal dan horizontal. Pembagian menurut garis horizontal, kekuasaan negara dapat dibagi ke dalam beberapa cabang kekuasaan yang dikaitkan dengan fungsi lembaga-lembaga negara tertentu (didasarkan atas sifat tugas yang bekerja sejenisnya, sehingga menimbulkan lembaga-lembaga negara) yaitu legislatif, eksekutif, dan yudikatif yang diatur dengan mekanisme chek and balance. Sedangkan pembagian kekuasaan secara vertikal, melahirkan garis hubungan antara pusat kekuasaan dan cabang-cabangnya (dalam hubungan "atasbawah"). Pembagian kekuasaan secara vertikal melahirkan dua hubungan yaitu: pertama, pelimpahan sebagian kekuasaan kepada orang-orang dari pusat 18 kekuasaan yang berada pada cabang-cabangnya, untuk menyelenggarakan kebijakan yang telah ditetapkan oleh pusat kekuasaan.

Sementara menurut Dharmawan (2008) dalam perspektif ketata-negaraan, kebijakan Otonomi Daerah (OTDA), pada taraf tertentu juga ikut memberikan kontribusi dalam 
memperburuk konflik sosial. Peristiwa konflik sosial yang berlangsung di Indonesia selama 10 tahun terakhir menunjukkan adanya titik berat yang nyata pada basis materialism, yakni konflik sosial yang digerakkan oleh gerakan sosial klasik yang sepenuhnya berorientasikan pada gugatan rasa keadilan materiil. Secara konkrit, konflik sosial yang mewujud dalam bentuk tuntutan pemenuhan kebutuhan demi menjaga kelangsungan kehidupan masyarakat.

Tujuan utama penyelenggaraan otonomi daerah menurut Mardiasmo (2002:46) adalah untuk meningkatkan pelayanan publik dan memajukan perekonomian daerah. Pada dasarnya terkandung tiga misi utama pelaksanaan otonomi daerah yaitu:

1. meningkatkan kualitas dan kuantitas pelayanan publik dan kesejahteraan masyarakat.

2. menciptakan efisiensi dan efektivitas pengelolaan sumber daya daerah, dan

3. memberdayakan dan menciptakan ruang bagi masyarakat untuk berpartisipasi.

\section{Faktor - faktor yang mempengaruhi otonomi daerah}

Keberhasilan atau kegagalan suatu daerah dalam pelaksanaan otonomi daerah dipengaruhi banyak faktor. Pemerintah daerah harus bisa mengendalikan faktor-faktor tersebut guna menciptakan pelaksanaan otonomi daerah yang sesuai dengan asas otonomi.

Menurut Kaho (2007:64) Faktor-faktor yang mempengaruhi pelaksanaan otonomi daerah adalah:

1) Manusia pelaksananya harus baik

Manusia pelaksananya harus baik adalah faktor yang esensial dalam penyelenggaraan pemerintah daerah. Pentingnya faktor ini, karena manusia merupakan subjek dalam setiap aktivitas pemerintahan. Manusialah yang merupakan pelaku dan penggerak proses mekanisme dalam sistem pemerintahan.

Oleh sebab itu, agar mekanisme pemerintahan tersebut berjalan dengan sebaik-baiknya, yakni sesuai dengan tujuan yang diharapkan, maka manusia atau subjek atau pelakunya harus baik pula. Pengertian baik disini meliputi (a) Mentalitasnya/moralnya baik dalam arti jujur, mempunyai rasa tanggung jawab yang besar terhadap pekerjaannya, dapat bersikap sebagai abdi masyarakat atau public servant, dan sebagainya; (b) Memiliki kecakapan/kemampuan yang tinggi untuk melaksanakan tugas-tugasnya.

2) Keuangan harus cukup dan baik

Keuangan disini mengandung arti setiap hak yang berhubungan dengan masalah uang, antara lain sumber pendapatan, jumlah uang yang cukup, dan pengelolaan keuangan yang sesuai dengan tujuan dan peraturan yang berlaku.

Faktor keuangan penting dalam setiap kegiatan pemerintahan, karena hampir tidak ada kegiatan pemerintahan yang tidak membutuhkan biaya. Makin besar jumlah uang yang tersedia, makin banyak pula kemungkinan kegiatan atau pekerjaan yang dapat dilaksanakan. Untuk menciptakan suatu Pemerintahan Daerah yang baik dan yang dapat melaksanakan tugas otonominya dengan baik, maka faktor keuangan ini mutlak diperlukan.

3) Peralatannya harus cukup dan baik

Pengertian peralatan disini adalah setiap benda atau alat yang dapat dipergunakan untuk memperlancar pekerjaan atau kegiatan Pemerintah Daerah. Peralatan yang baik (praktis, efisien dan efektif) dalam hal ini jelas diperlukan bagi terciptanya suatu Pemerintah Daerah yang baik. 
4) Organisasi dan manajemennya harus cukup dan baik

Organisasi yang dimaksudkan adalah organisasi dalam arti struktur yaitu susunan yang terdiri dari satuan-satuan organisasi beserta segenap pejabat, kekuasaan, tugasnya dan hubungannya satu sama lain dalam rangka mencapai tujuan tertentu.

Pencapaian sasaran pembangunan daerah melalui kebijakan otonomi masih dihadapkan pada beberapa kendala yang harus diatasi pemerintah daerah. Setiap daerah memiliki kendala yang berbeda sesuai dengan tingkat kesiapan dan kondisi rill daerah masing-masing. Beberapa kendala kendala utama antara lain (Bastian, $2006: 343$ ):

1. Belum memadai dan belum mantapnya kelembagaan di daerah, sehingga cenderung dapat menghambat pelaksanaan dan desentralisasi dan otonomi daerah.

2. Masih terbatasnya ketersediaan dana pembangunan, sementara tuntutan untuk mempercepat pembangunan semakin gencar.

3. Masih terbatasnya ketersediaan sarana dan prasarana asar di beberapa daerah.

4. Tidak meratanya ketersediaan sumber daya alam di beberapa daerah.

5. Kurang dan tidak meratanya SDM yang berkualitas. Padahal, SDM berkualitas dapat menciptakan lapangan kerja sendiri dan tumbuhnya reativitas di daerah.

6. Kendala alamiah, yaitu sumber daya alam daerah yang tidak sama.

7. Kendala institusional.

8. Kendala investasi (modal).

9. Kendala sumber keuangan daerah dalam APBD.

Dari uraian di atas, bisa disimpulkan bahwa keberhasilan penyelenggaraan otonomi daerah tidak bisa terlepas dari kemampuan keuangan yang dimiliki daerah tersebut. Dari beberapa faktor yang mempengaruhi pelaksanaan otonomi daerah, keuangan merupakan faktor yang sangat penting, karena semua kegitan yang akan dilaksanakan oleh Pemerintah Daerah membutuhkan dana/uang. Sehingga dalam pelaksanaan otonomi daerah, setiap daerah diharapkan mempunyai tingkat kemampuan keuangan yang baik dalam menjalankan roda pemerintahan. Dalam membiayai belanja daerah hendaknya penyumbang utama keuangan daerah berasal dari Pendapatan Asli Daerah.

\section{Kerangka pemikiran}

Dalam pelaksanaan pembangunan infrastruktur oleh pemerintah daerah yang terangkum dalam UU No. 32 Tahun 2004 tentang Pemerintahan Daerah yang menyebutkan Otonomi daerah adalah hak, wewenang, dan kewajiban daerah otonom untuk mengatur dan mengurus sendiri urusan pemerintahan dan kepentingan masyarakat setempat sesuai dengan peraturan perundang-undangan. UU No 32 Tahun 2004 yang telah mengalami perubahan UU No 23 Tahun 2014 dan perubahan kedua UU No 9 Tahun 2015 tentang Pemerintahan Daerah.

Pada penelitian ini penulis merujuk pada pemikiran rondinelli dan Cheema dalam hanif nurcholist (2005),ada beberapa faktor yang menjadi acuan keberhasilan dan kelemahan kebijakan desentralisasi, yaitu :

1. Efesiensi pelaksanaan

Efisiensi pemerintahan pusat dapat ditingkatkan karna pejabat-penjabat manajemen tidak menangani tugas-tugas rutin. Tugas rutin lebih efektif kalau dilakukan oleh staf lapangan atau pejabat local. 


\section{Lemahnya perencanaan}

Desentralisasi dapat menjadi alat untuk mengatasi hambatan-hambatan bawaan akibat perencanaan nasional yang terpisahkan dengan mendelegasikan kewenangan perencanaan den manajemen pembangunan yang lebih besar kepada pejabat lapangan yang dekat dengan masalah yang mereka hadapi kelemahan perencanaan terpusat akan teratasi.

Undang-undang Nomor 23 Tahun 2014 menyebutkan bahwa perencanaan pembangunan daerah disusun secara berjangka meliputi;

a) Rencana Pembangunan Jangka Panjang Daerah (RPJPD) untuk jangka waktu 20 tahun yang memuat visi, misi dan arah pembangunan yang mengacu pada RPJP nasional.

b) Rencana Pembangunan Jangka Menengah Daerah (RPJMD) untuk jangka waktu 5 tahun merupakan penjabaran visi, misi dan program kepala daerah yang penyusunannya berpedoman kepada RJPD dengan memperhatikan RPJMN.

c) Rencana Kerja Pemerintah Daerah (RKPD) merupakan penjabaran dari RPJMD untuk jangka waktu 1 tahun yang memuat rancangan kerangka ekonomi daerah dan prioritas pembangunan daerah beserta kerangka pendanaannya.

\section{3 . Defisit/surplus}

Defisit atau surplus anggaran yaitu selisih antara penerimaan pemerintah dengan pengeluaran pemerintah. Defisit anggaran terjadi apabila pengeluaran pemerintah lebih besar daripada penerimaan pemerintah, dalam hal ini pengeluaran rutin lebih besar dari tabungan yang dimiliki pemerintah. Pemerintah memiliki dua cara untuk membiayai defisit anggaran, pertama pemerintah menaikkan penerimaan pemerintah atau cara kedua pemerintah melakukan pinjaman luar negeri. Selain kedua cara tersebut pemerintah sebenarnya juga dapat melakukan pencetakan uang baru untuk membiayai defisit anggaran, tetapi pencetakan uang baru yang tidak terkendali dapat menyebabkan inflasi. Pengaruh defisit anggaran terhadap suatu perekonomian negara merupakan salah satu isu yang kontroversial. Sudut pandang pertama berpendapat defisit anggaran yang dibiayai oleh utang pemerintah dapat menyebabkan dampak seperti pengangguran, inflasi, tingginya suku bunga dan memburuknya nilai tukar suatu negara. Sedangkan sudut pandang kedua berpendapat bahwa defisit anggaran tidak memiliki dampak terhadap perekonomian (Solikin, 2003). 
Gambar 1.1

Kerangka Pemikiran

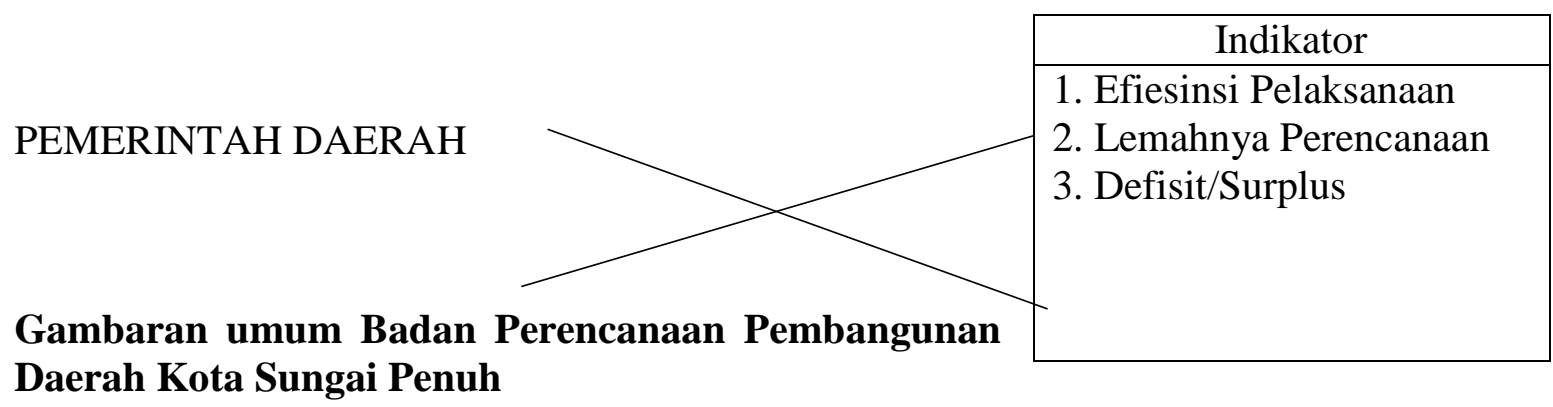

Undang-undang nomor 25 tahun 2004 tentang sistem perencanaan pembangunan nasional Undang-Undang ini mencakup landasan hukum di bidang perencanaan pembangunan baik oleh Pemerintah Pusat maupun Pemerintah Daerah. Dalam Undang-Undang ini ditetapkan bahwa Sistem Perencanaan Pembangunan Nasional adalah satu kesatuan tata cara perencanaan pembangunan untuk menghasilkan rencana pembangunan dalam jangka panjang, jangka menengah, dan tahunan yang dilaksanakan oleh unsur penyelenggara pemerintahan di pusat dan Daerah dengan melibatkan masyarakat.

\section{Visi dan misi Badan Perencanaan Pembangunan Daerah Kota Sungai Penuh Visi}

Mewujudkan Kota Sungai Penuh yang Profesional, Andal dan Efektif (Badan Perencanaan Pembangunan daerah proaktif) dalam Perencanaan Pembangunan Daerah.

1) Professional berarti mampu berperan sesuai dengan kapasitasnya sebagai institusi perencana pembangunan daerah secara efektif dan efisien dengan dukungan Sumber Daya Manusia yang kompeten dan kridibel, serta penerpan teknologi.

2) Andal berarti mampu melakukan Koordinasi, Integrasi, dan Sinkronisasi rencana Pembangunan sesuai dengan tujuan Pembangunan yang akan dicapai.

Efektif berarti mampu mencapai tujuan secara tepat dalam menjalankan tugas pokok dan fungsinya, sesuai dengan hasil yang diharapkan.

Misi

1) Memantapkan kualitas dan profesionalitas aparatur perencanaan.

2) Meningkatkan efektifitas dan efisiensi alur tata laksana internal.

3) Memperkuat system perencanaan pembangunan daerah.

4) Meningkatkan kualitas perencanaan pembangunan daerah 


\section{KESIMPULAN}

Efisiensi Pelaksanaan, mempunyai pengaruh penting dalam pembangunan infrastruktur di pemerintahan daerah Kota Sungai Penuh. Pemerintahan Kota Sungai Penuh belum cukup efisien dalam pembangunan infrastruktur di Kota Sungai Penuh. Karna ada di beberapa jalan di daerah Kota Sungai Penuh masih ada yang rusak, penyebabnya terjadi karna lemahnya sumberdaya manusia atau bisa jadi materialnya yang kurang bagus.

Lemahnya Perencanaan, perencanaan merupakan salah satu faktor penting dalam pemerintahan daerah untuk menjalankan pembangunan infrastruktur di Kota Sungai Penuh. Namun lemahnya perencanaan sering terjadi karna, faktor lingkungan, faktor sumberdaya manusia, faktor pendanaan, faktor perkembangan ilmu dan teknologi.

\section{UCAPAN TERIMAKASIH}

Diucapkan terima kasih kepada semua pihak yang telah berkontribusi dalam penulisan jurnal ini, sehingga jurnal ini dapat diselesaikan dengan baik. Dan juga terima kasih kepada penglola jurnal Qawwam, sehingga bisa dipublikasan di OJS Qawwam.

\section{DAFTAR PUSTAKA}

Ahmad, Yani. (2002). Hubungan Keuangan Antara Pemerintah Pusat dan Daerah. Jakarta :Grafindo.

Abdul Aziz Hakim. DistorsiSistem Pemberhentian (Impeachment) Kepala Daerah: di Era Demokrasi Langsung. Cetakan Pertama. TogaPress. Yogyakarta. 2006.

Pebi Julianto. 2018. Pengaruh Pengetahuan dan Keterampilan Terhadap Prestasi Kerja Pegawai Pada Mtsn Model Sungai Penuh. E Jurnal Administrasi Nusantara. Sungai Penuh.

Bastian, Indra. 2006. Akuntansi Sektor Publik. Penerbit BPPE, Universitas Gajah Mada, Yogyakarta.

Dr. J. Kaloh. 2007. Mencari Bentuk Otonomi Daerah. Jakarta :Rineka Cipta.

Pebi Julianto. 2018. Pengaruh Sistem Kearsipan Terhadap Efisiensi Kerja Pada koantor Camat Air Hangat Kabupaten Kerinci. E Jurnal Administrasi Nusantara. Sungai Penuh.

Deddy Supriady Bratakusumah \& Dadang Solihin.2004. Otonomi Penyelenggaran Pemerintahan Daerah. Jakarta : PT Gramedia Pustaka Utama

Gunawan, Imam. 2016, metode penelitian kualitatif : teori dan prakik. Jakarta :Fakultas Ilmu Sosial dan Ilmu Politik. 
Pebi Julianto. 2019. Pengaruh Disiplin Kerja Terhadap Prestasi Kerja Pegawai pada Puskesmas di kecamatan Depati VII Kabupaten Kerinci. E Jurnal Administrasi Nusantara. Sungai Penuh.

Paul H. Dauglas, Wahyudi Kumorotomo 1992. Ketentuan Transparansi dalam Pelayanan Publik.

Huda, Ni'matul, Otonomi Daerah filosopi, sejarahperkembangan dan problematika.

Yogyakarta: Pustaka Pelajara, 2005.

Hanif Nurcholist. 2005. Teori dan praktik pemerintahan dan otonomi daerah.

Jakarta : PT. Grasindo.

HestuCiptoHandoyo. 2009. Hukum Tata Negara.

Yogyakarta : Universitas Atmajaya.

InuKencanaSyafiie. 2003. Sistem Administrasi Negara Republik Indonesia.

Jakarta PT. Bumi Aksara.

Mardiasmp, Otonomi dan Manajemen Keuangan Daerah.

Yogyakarta: Andi, 2002.

Pebi Julianto. 2014. Evaluasi Pelaksanaan Program Satu milyar Satu kecamatan (Samisake) di kecamatan Depati Tujuh Kabupaten Kerinci Provinsi jambi tahun 2014. OSF Preprints. Jakarta.

Syaukani, Affan Gaffar, Ryass Rasyid. 2002. Otonomi Daerah dalam Negara Kesatuan.

Yogyakarta : Pustaka Pelajar.

Simanjuntak, Bungaran Antonius (editor). 2013. Dampak Otonomi Daerah di Indonesia ; Merangkai Sejarah Politik dan Pemerintahan Indonesia. Jakarta: Yayasan Pustaka Obor Indonesia.

Suparmoko. 2002. Ekonomi publik untuk keuangan dan pembangunan daerah. Andi : Yogyakarta.

Sugiyono. 2007. Metode Penelitian Kuantitatif Kualitatif dan R\&D.

Bandung: Alfabeta. 